\title{
Long term effects of untraditional irrigation water qualities on some soil properties and fertilization program
}

\author{
M. M. Shahin *, A. G. A. Mancy, S. A. Abdeen and K. M. Abdel Dayem \\ 1 Soils and Water Department, Faculty of Agriculture, Al-Azhar University, Cairo, Egypt \\ *Corresponding author E-mail: mshahin58@azhae.edu.eg (M. Shain).
}

\section{ABSTRACT}

High quality of water has the potential to allow maximum productivity under the good management practices of soil and water. This study objects to investigate the long term effects of different irrigation water qualities: Nile Water $(\mathrm{NW})$, Agricultural Drainage Water (ADW), Nile Water + Agricultural Drainage Water (NW+ADW), Nile Water+ Agricultural Drainage Water + Treated Waste Water (NW+ADW+TWW), and (USW) at AL-Jamalia region, Dakahlia governorate, Egypt. The results showed that the tested water samples belong to C3 and S1 classes of water, where EC values ranged from 0.74 to $2.25 \mathrm{dSm}^{-1}$ and less than 10 of SAR. The concentration of $\mathrm{Fe}, \mathrm{Mn}, \mathrm{Cu}$, and $\mathrm{Cd}$ are recorded in high concentration than permissible limits, while, the concentration of $\mathrm{Zn}$ and $\mathrm{Pb}$ were found to be within the range of permissible limits. The contribution of different irrigation water qualities on fertilization program, especially NPK was taken into consideration as a seasonal effect of these qualities. The long term effect of different irrigation water qualities on soil properties was based on the comparison between the soil irrigated by NW verses the soil irrigated by other qualities. The content of $\mathrm{N}, \mathrm{P}, \mathrm{K}, \mathrm{Fe}, \mathrm{Mn}, \mathrm{Cu}, \mathrm{Zn}, \mathrm{Cd}$, and $\mathrm{Pb}$ were higher in the soils irrigated by untraditional irrigation water qualities than the soil irrigated by NW, where the increases of these elements were higher in surface layers then subsurface layers for the studied soils. In conclusion the soils under study being heavy clay texture which needs attention to plowing dismantling and improving drainage in order to improve the movement of water, air and nutrients.

Keywords: Irrigation water quality; Soil properties; Fertilization program.

\section{INTRODUCTION}

The quality of irrigation water has a major role in crop production and soil properties. The usage of poor-quality of irrigation water has become a necessity to face the increasing demand for fresh water in many regions of the world. Most agricultural investors do not take into consideration the content of different sources of irrigation water (either conventional or unconventional sources), from soluble nutrients as one of the inputs for fertilization program, in spite of these sources can save money by reducing the added amounts of fertilizers, especially NPK according to the fertilizers recommendation.

The following chemical analysis should be estimated in irrigation waters: EC, soluble anions such as $\mathrm{CO}_{3}^{-}, \mathrm{HCO}_{3}^{-}, \mathrm{Cl}^{-}$and $\mathrm{SO}_{4--}^{-}$, and soluble cations such as $\mathrm{Na}^{+}, \mathrm{K}^{+}, \mathrm{Ca}^{++}, \mathrm{Mg}^{++}$where $\mathrm{Cl}^{-}$and $\mathrm{SO}_{4}{ }^{--}$are dominant anions. The water $\mathrm{pH}$ tends to be buffered by soil buffering action; furthermore most crops can tolerate a wide range of $\mathrm{pH}$, so the $\mathrm{pH}$ of the irrigation water is not an acceptable criterion of water quality. (USSL Staff, 1954). The quality and suitability of water for irrigation depends on the assessment of some parameters, such as electrical conductivity (EC), potential salinity (PS), sodium adsorption ratio (SAR), residual sodium carbonate (RSC), toxic and heavy metals (FAO 1976, Ayers; Westcot., 1985).

The quality of irrigation water indicates its suitability for use in agricultural production. High quality of water has the potential to allow maximum productivity under the good management practices of soil and water. Various irrigation water qualities contain many nutrients, among which is nitrogen, so it is recommended to monitored and estimated the content of these qualities from nitrogen as an integral part of the planned fertilization program. The concentration of nitrogen is usually less than $5 \mathrm{ppm}$ in most surface and groundwater. However, nitrogen concentration may increase above $50 \mathrm{ppm}$ in unusual groundwater. The nitrogen values ranging from 10 to $50 \mathrm{ppm}$ in wastewater especially from food processing and domestic sources, where $1 \mathrm{ppm}$ nitrogen equal $1 \mathrm{~kg} \mathrm{~N} / 1000$ $\mathrm{m}^{3}$ of water. Deep leaching of nitrogen fertilizers from below the root zone led to increase nitrogen concentration in drainage water (Ayers and Westcot., 1994). 
Water is an important factor to introducing some fertilizer nutrients for plant growth; if polluted, a harmful effect on plants, animals, and consequently on humans, is expected. Therefore, it is important to assess water quality, which is just as important of water quantity used for irrigation, in order to overcome any damage. Degradation of soil properties and crop quality may be occurred at the use of low water quality for irrigation (Hossain and Ahmed., 1999).

Fertilizers cost can be saved through different irrigation water qualities, especially with wastewater, which naturally contains many nutrients such as NPK. Therefore, an environmentally friendly closed system for nutrients was created to avoid the indirect return of them to water bodies. (Corcoran et al., 2010 and Drechsel et al., 2010). In this concern, Munir et al., (2007) they mentioned that the reuse of untraditional irrigation water qualities in agriculture, especially wastewater, largely concentrated on the seasonal effect of these qualities on plant growth with little attention to the changes that occur in physical, chemical and fertility status of soils as a long time effect of these untraditional irrigation water qualities.

The application of fertilizers can be reduced by using a mixture of urban wastewater (domestic, sewage and water from local industries), which can provides not only the quantities of water for irrigation but also some nutrients. The chickpea (Cicer arietinum L.) plants treated by wastewater for irrigation with the application of $\mathrm{K}$ at $20 \mathrm{~kg} \mathrm{ha}^{-1}$, exhibited better growth as compared with control treatment (wastewater). The application of $\mathrm{K}$ at $20 \mathrm{~kg} \mathrm{ha}^{-1}$ along with wastewater led to increase the growth parameters, and yield. (Hamid et al., 2013). Treated wastewater can be used for irrigation of wheat plant, but it must be considering the longterm effect of treated wastewater on human health and environment in terms of heavy metals and pathogens (Abdeen., 2016).

The soil properties (physical, chemical and microbial) cab changes as a result of application wastewater for a long time. Wastewater quality plays a major role for soil-affected properties. Among the physical soil properties affected by the addition of wastewater are the following: soil structure, soil porosity and soil size distribution. Also, application of irrigation water cause changes in chemical soil properties as a result of dissolved salts and heavy metals that presented in wastewater. These changes may be due to differences in the composition of the infiltrated solutions (Levy et al., 2011).

The first step towards ensuring sustainable agriculture is irrigation water assessment to provide the decision makers with required information regarding the problems and their causes in the irrigation system in order to solve these problems (Fan et al., 2018 and Akhtar et al., 2018).

The main objective of this study was to assessment of different irrigation water qualities and its effects as long term on soil properties as well as their contribution for fertilizer recommendations of crops commonly cultivated in the study area (AL-Jamalia region, Dakahlia governorate, Egypt).

\section{MATERIALS AND METHODS}

It is noteworthy to mention that the studied areas at AL-Jamalia region, Dakahlia governorate, Egypt, were selected according to the diversity of irrigation water used and the similarity of soil in texture (clay), crop pattern, wheat and broad bean as winter crops and rice, maize and cotton as summer crops, and farm management, types and doses of the fertilizers and pesticides. The qualities of irrigation water available in different locations were as follows:

Location 1: soil irrigated by Nile Water (NW) from Damietta branch, AL- Jamalia region at Zerzara village.

Location 2: soil irrigated by Agricultural Drainage Water (ADW) from El- Serw drain, ALJamalia region at Al- Misrab village.

Location 3: soil irrigated by mixed water; Nile Water + Agricultural Drainage Water (NW+ ADW), AL-Jamalia region at Al- Misrab village.

Location 4: soil irrigated by mixed water; Nile Water + Agricultural Drainage Water + Treated Wastewater (NW+ ADW+ TWW), AL-Jamalia region at at Abu- Hassan village.

Location 5: soil irrigated by Untreated Sewage Water (USW) from.

\section{Soil and water analysis}

Soil and water samples were collected from the studied sites. Soil samples were collected from surface $(0-30 \mathrm{~cm})$ and sub-surface soils (30$60 \mathrm{~cm})$ for each experimental site. Soil samples were taken to determine some physical and chemical properties as well as the status of some 
macronutrients (NPK), micronutrients (Fe, Zn, $\mathrm{Mn}$, and $\mathrm{Cu})$ and heavy metals $(\mathrm{Cd}$ and $\mathrm{Pb})$ in the studied samples. Soil samples were air dried, crushed and sieved through a $2.0 \mathrm{~mm}$ sieve for the determination of its physical and chemical properties. The characteristics of the studied samples, i.e. Particle size distribution, soil $\mathrm{pH}$, EC, soluble cations and anions, OM, CEC, calcium carbonate, available $\mathrm{N}, \mathrm{P}, \mathrm{K}$ were determined according to Page et al., (1982) and Klute (1986). Soil samples were extracted for available heavy metals in DTPA extract according to Lindsay and Norvell., (1978).

Water samples were collected from the different irrigation water qualities for two seasons, namely summer season, May to September of 2016 and winter season, November to March of 2016/2017. Water samples were preserved cool during transportation from the field to the laboratory. Water samples were filtrated using filter paper Whitman (No. 40) and subjected to chemical analysis to determine their chemical composition. The quality of irrigation water parameters included $\mathrm{pH}$, total soluble salts, potential salinity, sodium adsorption ratio (SAR), residual sodium carbonate (RSC), micronutrients, and certain heavy metals content in different qualities of irrigation water. The quality of irrigation water and suitability for irrigation was determined and calculated according to the parameters described by Ayers and Westcot., (1985).

According to water requirements for crops commonly cultivated in the areas under study ( $2100 \mathrm{~m}^{3} /$ feddan/season for maize as a summer crop and $1200 \mathrm{~m}^{3} /$ feddan/ season for wheat as a winter crop), the average concentrations of soluble NPK $(\mathrm{mg} / \mathrm{l})$ for summer and winter seasons of each irrigation water quality were calculated. The amount of soluble nutrients as a fertilizer's units of NPK (kg/feddan/ season) which will be introduced with the particular irrigation water quality was calculated. According to fertilizers recommendation (NPK) for Zea mays cv. hybrid $704\left(120 \mathrm{~N}, 30 \mathrm{P}_{2} \mathrm{O}_{5}\right.$ and 24 $\mathrm{K}_{2} \mathrm{O} \mathrm{kg} /$ feddan/season) and wheat Triticum aestivum cv. Shakha $93\left(75 \mathrm{~N}, 15 \mathrm{P}_{2} \mathrm{O}_{5}\right.$ and $24 \mathrm{~K}_{2} \mathrm{O} \mathrm{kg}$ /feddan/season), the fertilizer units were added after deduction the available amounts from other sources (either irrigation water or available in soil).

\section{RESULTS AND DISCUSSION}

\section{Assessment of different irrigation water qualities:}

The assessment of different irrigation water qualities including the following parameters:

\section{pH of Water}

The $\mathrm{pH}$ is an important factor that explains the suitability of water for a variety of purposes, inter alia, for irrigation. The averages values of different irrigation qualities in summer and winter seasons are given in Table 1 . The $\mathrm{pH}$ values of the irrigation water samples $\mathrm{NW}$, ADW, $(\mathrm{NW}+\mathrm{ADW}),(\mathrm{NW}+\mathrm{ADW}+\mathrm{TWW})$, and USW were 7.55, 7.42, 7.61, 7.80, and 7.59, respectively in summer season; while, in winter season, the values recorded 7.29, 7.33, 7.63, and 7.44 , respectively. It can be noticed that the tested samples showed $\mathrm{pH}$ values ranged from 7.29 7.80. it was considered in the normal limit (6.58.4) according to Ayers and Westcot., (1985).

\section{Electrical Conductivity (EC)}

The EC depends on the dissolved ions in the irrigation water and their charge and movement. When the EC of irrigation water is high, it shows that there is high concentration of ions in the irrigation water. The averages values of EC in different irrigation qualities are given in Table (1). The EC values of the studied irrigation water samples in the summer season ranged from 0.76 to $2.06 \mathrm{dSm}^{-1}$. While, the values ranged between 0.74 for (NW) to 1.94 for (ADW) $\mathrm{dSm}^{-1}$ in the winter season. The lowest value was observed at NW while, the highest value was observed at ADW. All of the samples belong to the $\mathrm{C} 3$ class of water, where EC values range from 0.74 to 2.25

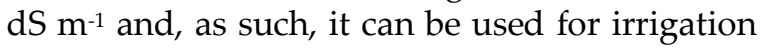
of the plants with tolerance to salt according to Richards., (1954).

\section{Sodium Adsorption Ratio (SAR)}

Sodium adsorption ratio (SAR) is an easily measured property that gives information on the comparative concentrations of sodium, calcium and magnesium. A high sodium ion in irrigation water affects the hydraulic conductivity of soil and creates water infiltration problems. Due high value of SAR, the soil becomes compact and hard at dry state and resultantly, reduces the movement of water and air in the soil and then affecting its structure. The SAR values for the studied samples table (1) were ranged from 2.78 - 
6.51 in the summer season. While, the values ranged between $3.14-5.49$ in the winter season. The lowest value was observed at NW. While, the highest value was observed at ADW. All the SAR values of tested samples belong to the S1 class of water, where SAR values less than 10 according to Richards., (1954).

\section{Residual Sodium Carbonates (RSC)}

Residual Sodium Carbonates (RSC) used to predict the additional sodium hazard associated with calcium carbonate precipitation involves calculation of the residual sodium carbonate. Determination of bicarbonate is an important procedure for assessing the quality of irrigation water. Soils irrigated with high RSC water can become infertile due to deposition of $\mathrm{Na}_{2} \mathrm{CO}_{3}(\mathrm{Li}$ et al., 2016).

The averages values of RSC observed with negative values in the studied samples of different irrigation water qualities in summer and winter season. This is may be ascribed to the addition of the various inorganic dissolved solids from the domestic and industrial wastes into the water resources. According to the recognized guidelines for water quality classification $<1.25$ it was under safe category for its use in irrigation (Eaton., 1950). Many authors have also reported negative RSC values for surface water to consider it safe use in agriculture through irrigation (Haritash et al., 2016; Sheriff and Hussain., 2017).

\section{Potential salinity}

The average potential salinity of the studied samples ranged between 5.15 to $13.14 \mathrm{meq} / \mathrm{l}$ in summer season. While, the values ranged between 4.26 and $11.82 \mathrm{meq} / \mathrm{L}$ for the studied samples in winter season. The lowest value was observed at NW. While, the highest value was observed at ADW. Potential salinity of irrigation water by pointing out that the suitability of water for irrigation is not only dependent on the concentration of soluble salts (Doneen., 1964). It has been reported that the low solubility salts precipitate and accumulate in the soil for successive irrigation whereas the concentration of highly soluble salts increases the salinity of the soil (Siamak and Srikantaswamy 2009).

\section{Irrigation water content from macronutrients}

The concentration of macronutrients could vary substantially depending on the source of the primary wastewater and the treatment process.
The data in Table 2 revealed that N, P and K concentration were varied not only among the irrigation water qualities but also according to the sampling season. The highest concentrations of $\mathrm{N}, \mathrm{P}$ and $\mathrm{K}$ were recorded with mixed water $(\mathrm{NW}+\mathrm{ADW}+\mathrm{TWW})$ at summer season while, the lowest concentrations were observed with NW at winter season. The highest values of $\mathrm{N}, \mathrm{P}$, and $\mathrm{K}$ in summer season were 22.68, 7.35, and $2.31 \mathrm{mg} / \mathrm{l}$, respectively. while, the lowest values were recorded 6.01, 3.00, and $0.65 \mathrm{mg} / 1$ respectively. On the other hand, the highest values of N, P and $\mathrm{K}$ in winter season were 22.61, 7.31, and 2.30 $\mathrm{mg} / \mathrm{L}$ respectively while, the lowest values were recorded 5.98, 3.01, and $0.65 \mathrm{mg} / \mathrm{l}$, respectively. Generally, the highest values were recorded at mixed water (NW +ADW + TWW) while, the lowest values were recorded at NW. These results could be enhanced by Drechsel et al., (2010) and Galavi et al., (2010), they reported that the nutrients naturally present in different irrigation water especially wastewater which allow savings of fertilizer expenses to be realized on the other hand, the concentrations of N, P and $\mathrm{K}$ in irrigation wastewater were higher than other irrigation water qualities.

\section{Irrigation water content of micronutrients and heavy metals}

Data in Table (3) indicated that the concentrations of $\mathrm{Fe}, \mathrm{Mn}, \mathrm{Zn}, \mathrm{Cu}, \mathrm{Cd}$, and $\mathrm{Pb}$ in different irrigation water qualities (NW), (ADW), $(\mathrm{NW}+\mathrm{ADW}),(\mathrm{NW}+\mathrm{ADW}+\mathrm{TWW})$, and (USW) in the winter season ranged between 0.65 to 2.32; 0.42 to $2.10 ; 0.23$ to $0.42 ; 0.78$ to $3.18 ; 0.05$ to 0.28 ; and 0.9 to $2.15 \mathrm{mg} \mathrm{l}^{-1}$, respectively. On the other hand, the values in summer season of Fe, Mn, Zn, $\mathrm{Cu}, \mathrm{Cd}$ and $\mathrm{Pb}$ were ranged between 0.9 to 2.32; 0.38 to $3.07 ; 0.48$ to $0.0 .89 ; 0.85$ to $4.50 ; 0.06$ to 0.95 , and 1.55 to $4.83 \mathrm{mg} \mathrm{l}^{-1}$ respectively. It can be noticed that, the values of the studied metal concentrations in the summer season were higher than winter season. Also, the highest values were observed at USW. While, the lowest values were observed at NW.

According to FAO., (1985), the permissible limits of $\mathrm{Mn}, \mathrm{Zn}, \mathrm{Cu}, \mathrm{Cd}$ and $\mathrm{Pb}$ for irrigation water are as follows: 0.20, 2, 0.20, 0.01 and 0.5 $\mathrm{ppm}$. Therefore, the concentrations of $\mathrm{Mn}, \mathrm{Cu}$, and $\mathrm{Cd}$ were recorded higher values of permissible limits. In general, a high proportional of $\mathrm{Cd}$ is usually associated with organic matter, particularly humic acid (Giller et al., 1998). Also, the recorded higher values of 
iron exceeded the permissible limit of iron (1 $\mathrm{mg} / \mathrm{l})$ recommended by Egyptian standards (Article 60 -law No. 48/1982). While, the concentrations of $\mathrm{Zn}$, and $\mathrm{Pb}$ were found to be within the range of permissible limits.

\section{Soil properties as affected by irrigation water qualities}

\section{Particle size distribution}

The particle size distribution of the collected soil samples of the studied locations were presented in Table (4). The soil particle size distribution was affected by irrigation water quality. Clay, silt and sand contents varied widely from 48.18 to $66.77,11.09$ to 14.14 and 22.14 to $33.38 \%$, respectively in surface soil samples (0-30). On the other hand, clay, silt and sand contents varied widely from 48.18 to 62.15 , 12.02 to 15.72 and 25.83 to $37.26 \%$, respectively in sub surface soil (30-60). The highest value of clay percentage $(66.77 \%)$ was observed in the surface layer of soil irrigated with (NW + ADW + TWW). While, the lowest value $(48.18 \%)$ was observed with the soil irrigated by USW in the sub surface soils. Also, the highest value of silt percentage $(15.72 \%)$ was observed at soil irrigated by NW in the sub surface soils sample. While, the lowest value (11.09\%) was observed at soil irrigated by (NW + ADW) at the sub surface soil. Lastly, the highest value of sand percentage $(37.26 \%)$ was observed at soil irrigated by USW in the sub surface soils. While, the lowest value $(22.14 \%)$ was observed with soil irrigated by (NW + ADW) at the surface soil. In this concern, Cornelis et al., (2001) reported that soil particle size distribution is a great importance to soil water movement. It has, therefore, been considered as a key soil physical parameter and related with water characteristics.

\section{Soil reaction $(p H)$}

Soil reaction represents one of the most important soil characteristics. The obtained results in Table (5) revealed that, $\mathrm{pH}$ values of the studied soils are neutral to alkaline as it's ranged from 7.7 to 8.02 in the surface layers. Also, the values were between 7.76 and 8.12 in the sub surface soil. The lowest value was recorded in the soil irrigated by NW while, the highest value was observed with the soil irrigated by USW. It can be noticed that, $\mathrm{pH}$ values affected by irrigation water quality. In this concern, Abegunrin et al.,
(2013) observed that soil $\mathrm{pH}$ affected by the irrigation of wastewater compared with soil irrigated with rainwater. On the contrary, Gurjar et al., (2017) reported that soil pH decreased significantly in the soil irrigated with wastewater compared to soil irrigated with groundwater as a control treatment. The reason for the fluctuation of the $\mathrm{pH}$ value could be explained by the different degrees of ammonification and nitrification of soil organic matter, anaerobic organic matter decomposition, and release and enrichment of metal ions (Rusan et al., 2007).

\section{Organic matter content (OM)}

Data in Table 5 show that, soil organic matter content (OM \%) ranges between 0.87 to $2.55 \%$ of the studied soil samples. The lowest value was observed at sub soil irrigated with NW while, the highest value was recorded at the surface soil irrigated with USW.

Generally, the surface layers are characterized by high values which tend to decrease with depth. Also, organic matter increased in soil irrigated with USW compared with NW. In this respect, Amin (2011) found that the soil irrigated with wastewater caused increase of organic matter. Also, the soils irrigated with sewage water under the surface irrigation system had higher values of OM \% Farrag, et al., (2017).

\section{Calcium carbonate}

The data of calcium carbonate $\left(\mathrm{CaCO}_{3}\right)$ of the studied soil samples are given in Table $5 . \mathrm{CaCO}_{3}$ $\%$ ranges between 3.11 and $5.8 \%$ of the studied soils. The lowest value was observed at soil irrigated with ADW while, the highest value was recorded at soil irrigated by USW.

\section{Cation exchange capacity (CEC)}

The results of cation exchange capacity (CEC) of the studied soil are given in Table 5. CEC cmolc $\mathrm{kg}^{-1}$ ranges between 41.00 and 46.62 cmolc kg-1 of the studied soils. The lowest value was observed at soil irrigated with NW at the sub surface layer while, the highest value was recorded at the surface soil irrigated with USW. Use of sewage water in irrigation also improved the chemical properties and fertility status of the soils Farrag, et al., (2017). 


\section{Exchangeable Cations as affected by different irrigation quality}

Exchangeable cations $\left(\mathrm{Ca}^{++}, \mathrm{Mg}^{++}, \mathrm{Na}^{+}\right.$and $\left.\mathrm{K}^{+}\right)$ of the studied soils are shown in Table 6. Exchangeable cations varied with application of irrigation water quality. The lowest values of $\mathrm{Ca}^{++}, \mathrm{Mg}^{++} \mathrm{Na}^{+}$and $\mathrm{K}^{+}$were recorded 13.16, 15.32, 6.31 and $4.49 \mathrm{cmol}_{\mathrm{c} \mathrm{kg}}{ }^{-1}$, respectively at the soils irrigated by NW. While, the highest values of $\mathrm{Ca}^{++}, \mathrm{Mg}^{++}, \mathrm{Na}^{+}$and $\mathrm{K}^{+}$were recorded $14.45,16.48$, 7.81 and $4.80 \mathrm{cmol}_{\mathrm{c} \mathrm{kg}}{ }^{-1}$, respectively at the soil irrigated with ADW and USW. Generally, the lowest values were observed at the soil irrigated the NW. While the highest values were observed at the soil irrigated with ADW or USW. Considering all data, relationship between organic carbon and CEC.

Regarding to the effect of irrigation water quality on Exchangeable Sodium Percentage (ESP), the data in Table 6 show that, the lowest value was recorded 14.55 at the surface soil irrigated with NW. While, the highest value was recorded 17.94 at the soil irrigated with ADW. Generally, ESP increased in all different irrigation water qualities compared with control treatment (NW). These results enhanced by Fonseca et al., (2007), they found that irrigation with wastewater alters soil chemistry, causing: slight decrease on soil acidity; marked increases in $\mathrm{Na}$ concentration and exchangeable sodium percentage (ESP); mixed effects on soil $\mathrm{K}$ and $\mathrm{Mg}$ and increase in exchangeable Ca.

\section{Soil salinity and soluble ions:}

Data in Table (7). show the long-term effect of different irrigation water qualities on electrical conductivity and soluble ions (cations and anions) of studied soil samples at different depths. The electrical conductivity of the studied soil samples ranged between 2.10 to $3.68 \mathrm{dSm}^{-1}$. The electrical conductivity decrease value in the soil irrigated with NW was higher than the decrease occurred in the soils irrigated by other water qualities. The EC values for the soils irrigated with different irrigation water qualities followed the descending order: ADW, $(\mathrm{NW}+$ ADW), USW, (NW + ADW +TWW), and finally NW. This effect may be attributed to the accumulation of dissolved salts; as the long term impact of these qualities of irrigation water on the studied soils. These results are in agreement with Mojiri and Aziz (2011), they found that the application of drainage water caused an increase of electrical conductivity (EC) and soluble ions. The highest values of EC at two depths were found with the soils irrigated with ADW, 3.68 and $3.59 \mathrm{dS} \mathrm{m}^{-1}$, while the lowest values were recorded with the soil irrigated with NW, 2.19 and $2.10 \mathrm{dS} \mathrm{m}^{-1}$, respectively.

Also, the soil irrigated with USW had higher electrical conductivity as compared to the soil irrigated by NW. The electrical conductivity although increased due to USW, it was within the tolerance limit to cause any soil salinity hazard (Kharche et al., 2011). On the other hand, the values of EC and soluble ions for surface layers $(0-30 \mathrm{~cm})$ in different studied areas were higher than subsurface layers $(30-60 \mathrm{~cm})$. This is may be due to the movement of saline solution and its evaporation at soil surface. This effect indicates that there is an obstruction of water movement and dissolved salts from surface to sub-surface layers. This may be explained on the basis of soil compaction, high clay content and evaporation of saline solution at soil surface.

As mentioned above with EC values, the concentration of both cations and anions at different depths of irrigated soil samples were corresponding with their EC values. The concentration of the cations and anions in the soil irrigated with NW were less than those of the soils irrigated with unconventional irrigation water qualities. The highest values of concentration were presented in the soil irrigated with ADW, while the lowest values were observed with the soil irrigated with NW.

\section{Effect of irrigation water qualities on available macronutrients and equivalent fertilizer units:}

The data in Table 8 illustrates the effect of different irrigation water qualities on the available NPK (mg kg-1 soil) in the investigated soils at different depths. The results indicated that the use of unconventional water ADW, (NW $+\mathrm{ADW}),(\mathrm{NW}+\mathrm{ADW}+\mathrm{TWW})$ and (USW) for irrigation increased the values of available NPK as compared to the soil irrigated by NW. The highest values of available NPK were found with the soil irrigated with USW; while the lowest values were recorded with the soil irrigated by NW. These data are in agreement with those obtained by Al Omron et al., (2012), they concluded that one of the most important effects of irrigation by treated sewage effluent is a positive effect on the content of soil organic matter. Also, the suspended, colloidal and 
dissolved solids present in wastewater contain some nutrients, which are essential for plant nutrition. They also added that, fertilization program of soil irrigated by treated wastewater could be change according to the quantity of nutrients which are presented in this quality of irrigation water.

Concerning the most readily available of macronutrients in soil, the data showed that potassium is the highest, followed by nitrogen and finally phosphorus, respectively. Also, the availability of NPK for surface layers more than in the subsurface layers. These results are in agreement with those obtained by Shahin and Alhajhoj. (2015), they found that the surface layer of soil profile $(0-30 \mathrm{~cm})$ contained more NPK than the subsurface layers (30-60). This increase of NPK in the soil surface and decrease in their contents with the depth may be attributed to the movement of irrigation water with depth. In other words, this may be due to the role of permeability of irrigation water through the soil. Knowledge of the $\mathrm{N}$ concentration in the irrigation water and the proper management of the load of N P K are essential to overcome problems associated with eventual high $\mathrm{N}$ concentration FAO., (2003).

Concerning of available phosphorus, the results indicated that the values amounted to $4.86,7.11,6.12,7.76$, and $8.10 \mathrm{mg} \mathrm{kg}^{-1}$ soil from 0 $30 \mathrm{~cm}$ depth. While, the values reached $3.62,6.93$, $5.31,6.81$, and $7.40 \mathrm{mgkg}^{-1}$ soil in subsurface layer of the soils irrigated by (NW), (ADW), (NW + $\mathrm{ADW}),(\mathrm{NW}+\mathrm{ADW}+\mathrm{TWW})$, and (USW), respectively. These results are in agreement with those recorded by Mohammad and Mazahreh., (2003) they noted that there were changes in soil fertility as affected by non-conventional irrigation water (wastewater), comparison with fresh and rainfall water as a source for irrigation, where extractable phosphorus was higher in soils subjected to wastewater than in soil treated with fresh or rainfall water.

The values of available $\mathrm{K}$ in soil irrigated by different water qualities at $0-30 \mathrm{~cm}$ depth were $198,298,219,327$ and $389 \mathrm{mg} \mathrm{kg}^{-1}$ soil. While, the values at 30-60 $\mathrm{cm}$ depth were 171, 245, 203, 305 and $325 \mathrm{mg} \mathrm{kg}^{-1}$ soil for the soils irrigated by $(\mathrm{NW}),(\mathrm{ADW}),(\mathrm{NW}+\mathrm{ADW}),(\mathrm{NW}+\mathrm{ADW}$ +TWW), and (USW), respectively. These results are in agreement with those obtained by Nyamangara and Mzezewa., (2000) they found that the concentration of $\mathrm{K}$ decreased with depth.
Based on the above results it can be concluded that the use of unconventional water (especially USW) for irrigation has increased the soil NPK contents compared with other different irrigation water qualities. This increase was highest in the surface soil $(0-30 \mathrm{~cm}$ depth) for the long period of irrigation by USW. This is attributed to the original high contents of these nutrients in this water quality. Therefore, soil content of NPK and equivalent fertilizer units ( $\mathrm{kg}$ fed $^{-1}$ ) should be taken into consideration in formulating the fertilization programmer according to crop needs especially in irrigated soils with unconventional irrigation water quality for long period FAO., (2003).

\section{Effect of irrigation water qualities on available micronutrients and heavy metals}

Table 9 presents the data of available some micronutrients and heavy metals $\mathrm{Fe}, \mathrm{Zn}, \mathrm{Mn}, \mathrm{Cu}$, $\mathrm{Cd}$ and $\mathrm{Pb}$ in soils irrigated by different irrigation water qualities at different soil depths. The data indicates that the available of elements ( $\mathrm{Fe}, \mathrm{Zn}$, $\mathrm{Mn}, \mathrm{Cu}, \mathrm{Cd}$ and $\mathrm{Pb} \mathrm{mg} \mathrm{kg-1}$ soil) in the soil irrigated with $\mathrm{NW}$ were less than those irrigated with others qualities. The use of unconventional irrigation water (ADW, NW + ADW, NW + ADW +TWW and USW) for long term increased the values of micronutrients ( $\mathrm{Fe}, \mathrm{Zn}, \mathrm{Mn}$, and $\mathrm{Cu} \mathrm{mg}$ $\mathrm{kg}^{-1}$ soil) and heavy metals ( $\mathrm{Cd}$ and $\mathrm{Pb} \mathrm{mg} \mathrm{kg}^{-1}$ soil) as compared to the soil irrigated by NW.

The highest values of micronutrients and heavy metals were found with the soil irrigated with USW; while, the lowest values were recorded with the soil irrigated with NW. These data were agreement with Hussein et al., (2008) and Al- Busaidi., (2015) they found that mixture of groundwater and drainage water $(\mathrm{GW}+\mathrm{DW})$, mixture of groundwater and tertiary treated wastewater (GW+TTWW) and mixture of groundwater, drainage water and tertiary treated wastewater (GW+DW+TTWW $)$ significantly increased available of $\mathrm{Fe}, \mathrm{Mn}, \mathrm{Cu}, \mathrm{Zn}, \mathrm{Cd}, \mathrm{Co}$, and $\mathrm{Ni}$ of the soil as compared with ground water (GW). It is noticed that the effect of different irrigation water qualities on micronutrients and heavy metals are in the following order: USW > $(\mathrm{NW}+\mathrm{ADW}+\mathrm{TWW})>\mathrm{ADW}>(\mathrm{NW}+\mathrm{ADW})>$ NW. The above descending order was corresponding with the concentrations of different elements with different irrigation water qualities. The values of available micronutrients $(\mathrm{Fe}, \mathrm{Zn}, \mathrm{Mn}$, and $\mathrm{Cu})$ as well as heavy metals $(\mathrm{Cd}$ 
and $\mathrm{Pb}$ ) were higher in the soil irrigated with USW at different depths $(0-30$ and $30-60 \mathrm{~cm})$ as compared with their values of soils irrigated with other different irrigation water qualities. The values of $\mathrm{Fe}, \mathrm{Zn}, \mathrm{Mn}, \mathrm{Cu}, \mathrm{Cd}$, and $\mathrm{Pb}$ in surface layer reached to $86.05,3.00,8.00,6.34,0.53$ and $10.50 \mathrm{mg} \mathrm{kg}{ }^{1}$ soil; while, the values reached to $81.79,2.83,6.93,5.52,0.45$, and $8.40 \mathrm{mg} \mathrm{kg}^{-1}$ soil with subsurface soil layer for the soil irrigated with USW, respectively. The lowest values of Fe, $\mathrm{Zn}, \mathrm{Mn}, \mathrm{Cu}, \mathrm{Cd}$, and $\mathrm{Pb}$ were recorded with the soil irrigated with NW.

The values with NW at surface soil layers reached to $36.72,0.48,3.06,1.85,0.25$, and 3.10 $\mathrm{mg} \mathrm{kg}^{-1}$ soil; while, the values in subsurface soil layers recorded 30.04, 0.38, 2.79, 1.25, 0.21 and $2.30 \mathrm{mg} \mathrm{kg}^{-1}$ soil, respectively.

\section{Contribution of irrigation water quality of fertilizer units}

The contributions of irrigation water quality in the supplying of nutrients for some commonly cultivated crops in the studied area are presented in Tables 10 and 11. The data show that the average amounts of soluble NPK and its equivalent from fertilizer units ( $\mathrm{kg} /$ feddan/season) which will be introduced with different irrigation water qualities during summer and winter seasons, for some commonly cultivated crops (maize as a summer crop and wheat as a winter crop) in the area under study. The calculation of supplying nutrients form different irrigation water qualities was taken into consideration the water requirement of maize and wheat were 2100 and $1200 \mathrm{~m}^{3} /$ feddan/season, respectively. It is worth mentioning that the arrangement of fertilizer nutrients in the different irrigation qualities during summer and winter seasons was as follows: $\mathrm{N}>\mathrm{P}>\mathrm{K}$.

The results indicated that the unconventional irrigation water (ADW, $(\mathrm{NW}+\mathrm{ADW}),(\mathrm{NW}+$ ADW + TWW), and USW contains high average amount of fertilizer units ( $\mathrm{kg} /$ feddan/season) as compared to the average amount of fertilizer units which is expected to enter with NW .This trend will be observed for two seasons (summer and winter). The different irrigation water qualities as a source of fertilize units for NPK can be descending order as follows: (NW + ADW + TWW),

USW, $(\mathrm{NW}+\mathrm{ADW}), \mathrm{ADW}$ and NW. These data were agreement with Al Omron et al.,
(2012), they concluded that calculating the nutrients present in the treated effluent as part of the overall fertilization program of the irrigated crops is necessary. The highest values of fertilizer units ( $\mathrm{kg} /$ feddan/season) during summer season were found with mixed water (NW + ADW +TWW) as follows: $47.62 \mathrm{~N}, 35.06 \mathrm{P}_{2} \mathrm{O}_{5}$ and 5.82 $\mathrm{K}_{2} \mathrm{O}$. While, the lowest values during summer season were recorded with NW as follows: 12.63 $\mathrm{N}, 14.43 \mathrm{P}_{2} \mathrm{O}_{5}$, and $1.64 \mathrm{~K}_{2} \mathrm{O}$. The highest values of fertilizer units $(\mathrm{kg} /$ feddan/season) during winter season were found with mixed water (NW + ADW +TWW) as follows: $27.13 \mathrm{~N}, 20.09 \mathrm{P}_{2} \mathrm{O}_{5}$, and $3.31 \mathrm{~K}_{2} \mathrm{O}$, respectively; while, the lowest values during winter season were recorded with $\mathrm{NW}$ as follows: $7.18 \mathrm{~N}, \quad 8.27 \mathrm{P}_{2} \mathrm{O}_{5}$, and $0.94 \mathrm{~K}_{2} \mathrm{O}$, respectively.

\section{Recommendation doses of NPK after calculate the contribution of irrigation water and soil from fertilizer units for some crops in the study area}

Based on the above results of soil and different irrigation water quality analysis as shown in Tables 8, 10 and 11, the recommendation doses of NPK will be change according to the contribution of both irrigation water quality and soil from the fertilizer units that will be deducted from the fertilizer recommendation for common crops cultivated in the study area (e.g. maize as summer crop and wheat as winter crop). The recommendation doses of NPK for maize as summer crop were 120, 30 and 24 (kg/feddan/ season) as $\mathrm{N}, \mathrm{P}_{2} \mathrm{O}_{5}$ and $\mathrm{K}_{2} \mathrm{O}$; respectively. Also, the water requirement of maize crop was $2100 \mathrm{~m}^{3}$ /fedden/ season. The recommendation doses of NPK for wheat as winter crop were 75, 15, and 24 ( $\mathrm{kg} /$ feddan/season) as $\mathrm{N}, \mathrm{P}_{2} \mathrm{O}_{5}$ and $\mathrm{K}_{2} \mathrm{O}$; respectively. Also, the water requirement for wheat crop was $1200 \mathrm{~m}^{3} /$ feddan/ growth season.

According to the data in Tables 12 and 13, the order of different irrigation water qualities for its contribution in providing part of the fertilizer requirement for maize and wheat crops was as follows: $(\mathrm{NW}+\mathrm{ADW}+\mathrm{TWW})>(\mathrm{USW})>(\mathrm{NW}+$ $\mathrm{ADW})>(\mathrm{ADW})>(\mathrm{NW})$. These data were agreement with Al Omron et al., (2012).

Data in Table 12 indicated that the fertilizer units $\left(\mathrm{N}, \mathrm{P}_{2} \mathrm{O}_{5}\right.$, and $\mathrm{K}_{2} \mathrm{O} \mathrm{kg} /$ feddan/ season) for maize as a summer crop which must be added after deducted the contribution of irrigation water and soil changed. The values of recommended doses of $\mathrm{N}, \mathrm{P}_{2} \mathrm{O}_{5}$, and $\mathrm{K}_{2} \mathrm{O}$ 
$\mathrm{kg} /$ feddan/ season for maize crop become (53, 4.44 , and -215.24 for the soil irrigated by NW), (15.94, -7.44 and -338.28 for the soil irrigated by ADW), (23.67, -8.73, and -243.15 for the soil irrigated by NW + ADW ), (-6.94, -22.83 , and 374.22 for the soil irrigated by NW + ADW + TWW) and ( $-10.20,-20.77$ and -446.97 for the soil irrigated by USW) respectively, where a negative sign indicates that there is an available amounts from unites of fertilizers. Also, Data in Table 12 showed the values of recommended doses of $\mathrm{N}, \mathrm{P}_{2} \mathrm{O}_{5}$, and $\mathrm{K}_{2} \mathrm{O} \mathrm{kg} /$ feddan/ season for wheat crop become $(13.45,-4.40$, and -214.54 for the soil irrigated by NW), (-15.50, -13.40 and 336.26 for the soil irrigated by ADW), (-6.08, 13.17 , and 241.27 for the soil irrigated by NW + ADW ), (-31.45, -22.86 and -371.71 for the soil irrigated by ( NW + ADW + TWW) and (-37.69, 22.01 , and -445.17 for the soil irrigated by USW) respectively, where a negative sign indicates that there is an available amounts from unites of fertilizers in the soils.

\section{CONCLUSION}

Based on the above discussion it can be concluded that, it should be determining the irrigation water quality in the regions which irrigated with untraditional irrigation water quality before planting. The tested samples belong to the $\mathrm{C}_{3}$ class of water; it can be used for irrigation of the plants with tolerance to salt. Also, water samples belong to the $S_{1}$ class of water. $\mathrm{Fe}, \mathrm{Mn}, \mathrm{Cu}$, and $\mathrm{Cd}$ were recorded in high concentration than permissible limits. While, the concentration of $\mathrm{Zn}$ and $\mathrm{Pb}$ were found to be within the range of permissible limits. This study confirmed on the importance of irrigation water quality especially, unconventional qualities as a source for providing part of the fertilizer requirements especially, NPK. Knowing the amount of nutrients fertilizers (NPK), introduced with irrigation water quality during the growing season as the seasonal effect. The accumulated amount of these nutrients in the soil as a result of the long term effect of different irrigation water qualities should be taken into consideration for fertilization program. Therefore, soil and irrigation water should be analyzed before planting of different crops, especially in areas that use unconventional irrigation water quality to identify the contribution of soil and irrigation water to provide part of the fertilizer requirements which finally reflects on the fertilizer recommendation and then the costs of agricultural investment. Although it is necessary to use unconventional water for irrigation, which mathematically provides part of the fertilizer needs, because these qualities not only contains salts and nutrients, but also contains pathogens and pollutants, especially sewage water and wastewater that need further more study because of their impact on the ecosystems.

\section{REFERENCES}

Abdeen, S.A., 2016. Influence of using treated wastewater with moringa seeds and chitosan on wheat growth and uptake of nutrients and heavy metals. J. Egypt. Acad. Soc. Environ. Dev. 17 (1), 157-168.

Abegunrin, T.P., Awe, G.O., Idowu, D.O., Onigbogi, O.O., Onofua, O.E., 2013. Effect of kitchen wastewater irrigation on soil properties and growth of cucumber (Cucumis sativus). J. Soil Sci. Environ. Manage. 4 (7), 139145.

Akhtar, F., Awan, U., Tischbein, B., Liaqat, U., 2018. Assessment of irrigation performance in large river basins under data scarce Environment-A Case of Kabul River Basin, Afghanistan. Remote Sens. 10, 972.

Al-Busaidi, A., Al-Yahyai, R., Ahmed, M., 2015. Heavy metal concentrations in soils date palms irrigated by groundwater and treated wastewater. Pak. J. Sci. 52 (1), 129-134.

Al-Omran, M.A., El-Maghraby S.E., Nadeem, M.E., El- Eter, A.M., Al-Mohani, H., 2012. Long term effect of irrigation with the treated sewage effluent on some soil properties of AlHassa Governorate, Saudi Arabia. J. Saudi Soc. Agri. Sci. 11, 15-18.

Amin, M., 2011. Effect of municipal waste water on physical and chemical properties of saline soil. J. Biol. Environ. Sci. 5 (14), 71-76.

Ayers, R.S., Westcot, D.V., 1985. Water quality for agriculture. FAO Irrigation and Drainage, Paper No. 29. FAO, Roma, p.174

Ayers, R.S., Westcot, D.V., 1994. Water quality for agriculture. Food and Agriculture Organization of the United Nations. Irrigation and drainage paper, 29.

Corcoran, E., Nellemann, C., Baker, E., Bos, R., Osborn, D., Savelli, H., 2010. Sick Water? the central role of wastewater management in sustainable development: a rapid response assessment; Earthprint: Arendal, Norway. 
Cornelis, W.M., Ronsyn, J., van Meirvenne, M., 2001. Evaluation of pedo transfer functions for predicting the soil moisture retention curve. Soil Sci. Soc. Am. J. 65, 638-648.

Doneen, L.D., 1964. Notes on water quality in agriculture. Water Science and Engineering, University of California, Davis.

Drechsel, P., Scott, A., Sally, R., Redwood, M., Bachir, A., 2010. Wastewater irrigation and health: assessing and mitigating risk in lowincome countries; International Water Management Institute, Ed.; Earthscan: London, UK.

Eaton, E.M., 1950. Significance of carbonate in irrigation water. Soil Sci. 69,123-133.

Fan, Y., Gao, Z., Wang, S., Chen, H., Liu, J. 2018. Evaluation of the water allocation and delivery performance of Jiamakou irrigation scheme. Shanxi, China. Water 10, 654.

FAO, 1976. Water quality for agriculture" Irrigation and Drainage paper 29.

FAO, 1985. Water Quality for Agriculture. Paper No. 29 (Rev. 1) UNESCO, Publication, Rome.

FAO, 2003. Food and Agriculture Organization of the United Nations. Agriculture, food and water. A contribution to the World Water Development Report.

Farrag, H.M., El-Desoky, M.A., Basha, A.A., Roshdi, N.M., 2017. Long-term impact of treated sewage water on some soil properties and nutrients status in Luxor Governorate, Egypt. Egypt. J. Soil Sci. 57 (1), 1-14.

Fonseca, A.F., Herpin, U., Paula, A.M., Victoria, R.I., Melfi, A.I., 2007. Agricultural use of treated sewage effluents: agronomicalenvironmental implications and perspectives for Brazil. Sci. Agric., 64 (2), 194-209.

Galavi, M., Jalali, A., Ramroodi, M., Mousavi, S.R., Galavi, H., 2010. Effects of treated municipal wastewater on soil chemical properties and heavy metal uptake by Sorghum (Sorghum bicolor L.). J. Agric. Sci., 2, 235-241.

Giller, K.E., Witter, E., Mcgrath, S.P., 1998. Toxicity of heavy metals to microorganisms and microbial processes in agricultural soils: a review. Soil Biol. Biochem. 30 (10 - 11), 1389414.

Gurjar, O.P., Meena, R., Latare, A. M., Rai,S., Kant, S., Kumar, A., Kumar, A., Sheshama, M.K., 2017. Effects of sewage wastewater irrigation compare to ground water irrigation on soil physicochemical properties. Int. J. Chem. Stud. 5 (6), 265-267.

Hamid, I.T., Olubukola, O.B., Maria, H.H., Arif, I., 2013. Urban wastewater irrigation and its effect on growth, photosynthesis and yield of chickpea under different doses of potassium. Soil Sci. Plant Nutr. 59 (2), 156-167.

Haritash, A.K., Gaur S., Garg, S., 2016. Assessment of water quality and suitability analysis of river Ganga in Rishikesh, India. Appl. Water. Sci. 6, 383-392.

Hossain, M., Ahmed, M., 1999. Ground water quality of Muktagacha aquifer for irrigation. Bangladesh J. Agric. Res. 24 (1), 141-152.

Hussein, A.H.A., Al-Dakheelm Y.Y., Shahin, M., Massoud, M.A., 2008. Evaluating different types of irrigation water and its effect on level of heavy metals in soil and plant in Al- Hassa Oasis, KSA. Conference: WSTA Eighth Gulf Water Conference, Kingdom of Bahrain, 3-6 March, Bahrain, D1-11.

Kharche, V.K., Desai, V.N., Pharande, A.L., 2011. Effect of sewage irrigation on soil properties, essential nutrients and pollutant element status of soils and plants in a vegetable growing area around Ahmednagar city in Maharashtra. J. Ind. Soc. Soil Sci. 59, 177-184.

Klute, A., 1986. Methods of Soil Analysis. Part 1. Physical and mineralogical Methods 2nd Ed., Amer. Soc. Agron. Monograph No. 9 Madison, Wisconsin, USA.

Levy, G., Fine, P., Bar-Tal, A., 2011. Treated Wasterwater in Agriculture: Use and Impacts on the Soil Environments and Crops. John Wiley \& Sons, Hoboken, NJ, p. 464.

Li, P., Zhang, Y., Yang, N., Jing, L., Yu, P., 2016. Major ion chemistry and quality assessment of groundwater in and around a mountainous tourist town of China. Expo. Health. 8, 239252.

Lindsay, W.L., Norvell, W.A., 1978. Development of a DTPA soil test for zinc, iron, manganese, and copper 1. Soil Sci. Soc. Am. J. 42 (3), 421428.

Mohammad, M.J., Mazahreh, N., 2003. Changes in soil fertility parameters in response to irrigation of forage crops with secondary treated wastewater. Commun. Soil Sci. Plant Analysis, 34, 1281-1294.

Mojiri, A., Aziz, H.A., 2011. Effects of municipal wastewater on accumulation of heavy metals in soil and wheat (Triticum aestivum L.) with 
two irrigation methods. Roman. Agric. Res. 28, 217-22.

Munir, J.M.R., Sami, H., Laith, R., 2007. Long term effect of wastewater irrigation of forage crops on soil and plant quality parameters. Desalination Desalination, 215 (1-3), 143-152.

Nyamangara, J., Mzezewa, J., 2000. The effects of long-term sludge application on $\mathrm{Zn}, \mathrm{Cu}, \mathrm{Ni}$, and $\mathrm{Pb}$ levels in clay loam soil under pasture grass in Zimbabwe. J. Agric. Ecosyst. Environ. 73, 199-204.

Page, A.L., Miller, R.H., Keeny, D.R., 1982. Methods of Soil Analysis. Part П. Chemical and microbiological properties 2nd Ed., Amer. Soc. Agron. Monograph No. 9 Madison, Wisconsin, USA.

Richards, L.A., 1954. Diagnosis and Improvement of saline and alkali soils. USDA Agricultural Handbook No. 60, US Department of Agriculture, Washington DC.

Rusan, M.J.M., Hinnawi, S., Rousan, L., 2007. Long-term effect of wastewater irrigation of forage crops on soil and plant quality parameters, Desalination, 215, 143-152.

Shahin, M.M., Alhajhoj, M.R., 2015. Effect of different irrigation water qualities on the content of some macro and micronutrients in leaves fruit, as well as yield and fruit quality of some date palm cultivars in Al- Hassa Oasis, Saudi Arabia. Middle East J. Agric. Res., 4 (4), 834-847.

Sheriff, K.M.M., Hussain A.Z., 2017. Evaluation of groundwater quality and its suitability for irrigation use on the bank of Noyyal river at Tiruppur, Tamilnadu, Ind. Env. Poll. Prot. 2 (3), 100-111.

Siamak, G., Srikantaswamy, S., 2009. Analysis of agricultural impact on the Cauvery river water around KRS dam. World Appl. Sci. J. 6 (8), 1157-1169.

USS Staff, 1954. Diagnosis and Improvement of saline and alkali soil. L.A. Richard (Ed,) Agricultural Handbook No. 60. United State Dept. of Agriculture, US Government printing office, Washington DC., USA. Young, A. (1976). Tropical soils and soil survey; Cambridge University press.

Xia, J.B., Xie, W.J., Sun, J.K., Liu, J.T., Liu, Q., Lu, Z.H., 2011. Effects of papermaking wastewater irrigation on reed growth and its oil improvement. J. Soil Water Conserv. 25, 110109. 
Table 1. The chemical composition of different irrigation water qualities in the study area at summer and winter seasons.

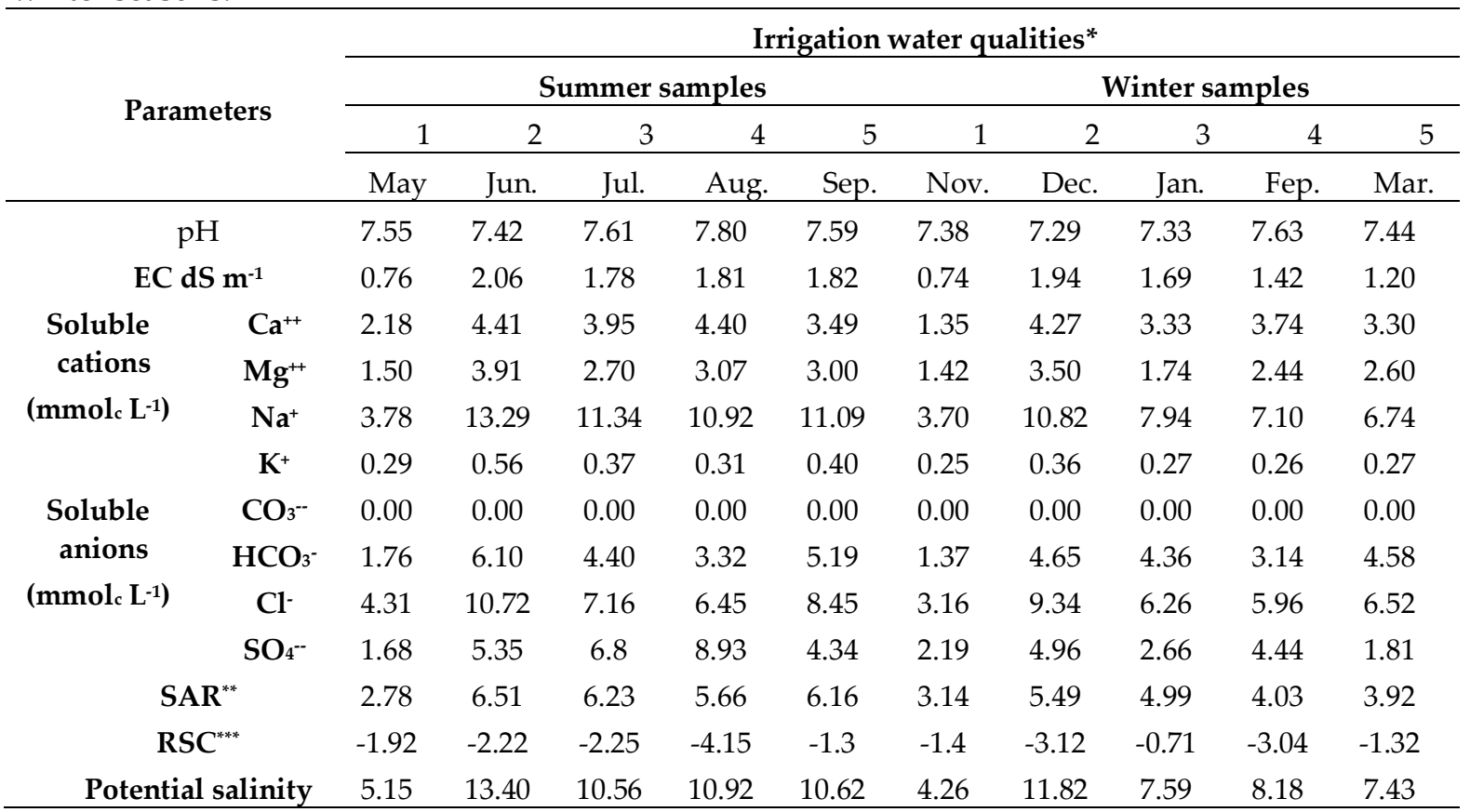

*Irrigation water qualities: -

1- $\quad$ Nile Water: NW (Damietta branch, AL- Jamalia region at Zerzara village).

2- $\quad$ Agricultural Drainage Water : ADW (El- Serw drain, AL- Jamalia region at Al- Misrab village)

3- $\quad$ Nile Water + Agricultural Drainage Water: NW+ADW (AL-Jamalia region at Al- Misrab village)

4- $\quad$ Nile Water + Agricultural Drainage Water +Treated Wastewater: NW+ADW+TWW (AL-Jamalia region at Abu- Hassan village)

5- $\quad$ Untreated Sewage Water: USW (Bahr Al- Baqar Drain, AL- Jamalia region)

** SAR (Sodium Adsorption Ratio), ${ }^{* * *}$ RSC (Residual Sodium Carbonate)

Table 2. Macronutrient concentrations $\left(\mathrm{mgl}^{-1}\right)$ in different irrigation water qualities at winter and summer seasons.

\begin{tabular}{ccccccc}
\hline \multirow{2}{*}{$\begin{array}{c}\text { Irrigation water } \\
\text { qualities * }\end{array}$} & \multicolumn{3}{c}{ Winter season } & \multicolumn{3}{c}{ Summer season } \\
\cline { 2 - 7 } & $\mathrm{N}$ & $\mathrm{P}$ & $\mathrm{K}$ & $\mathrm{N}$ & $\mathrm{P}$ & $\mathrm{K}$ \\
\hline NW & 5.98 & 3.01 & 0.65 & 6.01 & 3.00 & 0.65 \\
ADW & 15.00 & 4.41 & 1.85 & 15.03 & 4.40 & 1.86 \\
NW+ ADW & 16.35 & 5.15 & 1.72 & 16.43 & 5.14 & 1.73 \\
NW +ADW +TWW & 22.61 & 7.31 & 2.30 & 22.68 & 7.35 & 2.31 \\
USW & 19.33 & 6.72 & 1.65 & 19.39 & 6.70 & 1.66 \\
\hline
\end{tabular}

Irrigation water qualities*: Nile Water (NW), Agriculture Drainage Water (ADW), Treated Waste Water (TWW) and Untreated Sewage Water (USW). 
Table 3. Micronutrient and heavy metals concentrations $\left(\mathrm{mg} \mathrm{L}^{-1}\right)$ in different irrigation water qualities at winter and summer seasons

\begin{tabular}{|c|c|c|c|c|c|c|c|c|c|c|c|c|}
\hline \multirow{2}{*}{$\begin{array}{l}\text { Irrigation } \\
\text { water } \\
\text { qualities }\end{array}$} & \multicolumn{6}{|c|}{ Winter season } & \multicolumn{6}{|c|}{ Summer season } \\
\hline & $\mathrm{Fe}$ & $\mathrm{Mn}$ & $\mathrm{Zn}$ & $\mathrm{Cu}$ & $\mathrm{Cd}$ & $\mathrm{Pb}$ & $\mathrm{Fe}$ & $\mathrm{Mn}$ & $\mathrm{Zn}$ & $\mathrm{Cu}$ & $\mathrm{Cd}$ & $\mathrm{Pb}$ \\
\hline NW & 0.65 & 0.42 & 0.23 & 0.78 & 0.05 & 0.90 & 0.90 & 0.38 & 0.48 & 0.85 & 0.06 & 1.55 \\
\hline ADW & 1.58 & 1.32 & 0.33 & 2.26 & 0.15 & 1.52 & 1.76 & 1.65 & 0.63 & 3.08 & 0.23 & 2.70 \\
\hline NW+ ADW & 1.37 & 0.93 & 0.26 & 1.79 & 0.11 & 1.12 & 1.36 & 1.08 & 0.48 & 2.17 & 0.18 & 2.05 \\
\hline $\begin{array}{c}\text { NW +ADW } \\
\text { +TWW }\end{array}$ & 1.82 & 1.56 & 0.35 & 3.12 & 0.19 & 1.60 & 2.30 & 2.12 & 0.69 & 3.20 & 0.30 & 3.41 \\
\hline USW & 2.32 & 2.10 & 0.42 & 3.18 & 0.28 & 2.15 & 2.32 & 3.07 & 0.89 & 4.50 & 0.95 & 4.83 \\
\hline
\end{tabular}

Irrigation water qualities*: Nile Water (NW), Agriculture Drainage Water (ADW), Treated Waste Water (TWW) and Untreated Sewage Water (USW).

Table 4. Long term effect of different irrigation water qualities on soil particles size distribution at different soil depths.

\begin{tabular}{cccccc}
\hline \multirow{2}{*}{ Irrigation water qualities } & Depth cm & \multicolumn{3}{c}{ Particles size distribution } & \multirow{2}{*}{$\begin{array}{l}\text { Texture } \\
\text { class }\end{array}$} \\
\cline { 3 - 5 } & & Sand \% & Silt $\%$ & Clay $\%$ & \\
\hline NW & $0-30$ & 33.37 & 14.14 & 52.49 & Clay \\
ADW & $30-60$ & 32.48 & 15.72 & 51.80 & Clay \\
& $0-30$ & 31.59 & 13.30 & 55.11 & Clay \\
NW + ADW & $30-60$ & 34.08 & 14.52 & 51.40 & Clay \\
NW + ADW +TWW & $0-30$ & 22.14 & 11.09 & 66.77 & Clay \\
& $30-60$ & 25.83 & 12.02 & 62.15 & Clay \\
& $0-30$ & 22.05 & 11.18 & 66.77 & Clay \\
USW & $30-60$ & 33.57 & 13.63 & 52.80 & Clay \\
& $0-30$ & 33.48 & 13.72 & 52.80 & Clay \\
& $30-60$ & 37.26 & 14.56 & 48.18 & Clay \\
\hline
\end{tabular}

Irrigation water qualities*: Nile Water (NW), Agriculture Drainage Water (ADW), Treated Waste Water (TWW) and Untreated Sewage Water (USW) 
Table 5. Long term effect of different irrigation water qualities on some chemical properties of the studied soil samples at different soil depths.

\begin{tabular}{cccccc}
\hline Irrigation water qualities & $\begin{array}{c}\text { Depth } \\
\mathrm{Cm}\end{array}$ & $\mathrm{pH}$ & $\begin{array}{c}\mathrm{OM} \\
(\%)\end{array}$ & $\begin{array}{c}\mathrm{CaCO}_{3} \\
(\%)\end{array}$ & $\begin{array}{c}\mathrm{CEC} \\
\mathrm{cmol}_{\mathrm{kg}} \mathbf{~}^{-1}\end{array}$ \\
\hline NW & $0-30$ & 7.70 & 0.94 & 3.86 & 44.06 \\
& $30-60$ & 7.76 & 0.87 & 3.22 & 41.00 \\
ADW & $0-30$ & 7.92 & 1.05 & 3.11 & 45.36 \\
NW + ADW & $30-60$ & 8.12 & 1.00 & 4.79 & 43.54 \\
& $0-30$ & 8.02 & 1.35 & 4.34 & 44.62 \\
NW +ADW+ TWW & $30-60$ & 8.09 & 1.17 & 4.94 & 41.05 \\
& $0-30$ & 7.92 & 2.04 & 4.24 & 44.05 \\
USW & $30-60$ & 8.02 & 1.96 & 4.36 & 42.83 \\
& $0-30$ & 7.72 & 2.55 & 5.80 & 46.62 \\
& $30-60$ & 8.12 & 2.17 & 4.61 & 41.05 \\
\hline
\end{tabular}

Irrigation water qualities*: Nile Water (NW), Agriculture Drainage Water (ADW), Treated Waste Water (TWW) and Untreated Sewage Water (USW).

Table 6. Long term effect of different irrigation water qualities on the Exchangeable Cations ( $\left.\mathrm{cmol}_{\mathrm{ckg}}{ }^{-1}\right)$ of the studied soil samples at different soil depths.

\begin{tabular}{|c|c|c|c|c|c|c|}
\hline \multirow{2}{*}{$\begin{array}{l}\text { Irrigation water } \\
\text { qualities* }^{*}\end{array}$} & \multirow{2}{*}{ Depth cm } & \multicolumn{4}{|c|}{$\begin{array}{l}\text { Exchangeable cations } \\
\qquad \mathrm{cmol}_{\mathrm{c}} \mathrm{kg}^{-1}\end{array}$} & \multirow{2}{*}{$\mathrm{ESP}^{* *}$} \\
\hline & & $\mathrm{Ca}^{++}$ & $\mathrm{Mg}^{++}$ & $\mathrm{Na}^{+}$ & $\mathrm{K}^{+}$ & \\
\hline \multirow[t]{2}{*}{ NW } & $0-30$ & 13.91 & 13.05 & 6.41 & 4.60 & 14.55 \\
\hline & $30-60$ & 13.16 & 15.32 & 6.31 & 4.49 & 15.39 \\
\hline \multirow{2}{*}{ ADW } & $0-30$ & 14.23 & 16.37 & 7.70 & 4.49 & 16.98 \\
\hline & $30-60$ & 14.45 & 16.48 & 7.81 & 4.60 & 17.94 \\
\hline \multirow{2}{*}{$\mathrm{NW}+\mathrm{ADW}$} & $0-30$ & 13.70 & 16.05 & 6.85 & 4.71 & 16.46 \\
\hline & $30-60$ & 13.59 & 15.94 & 6.85 & 4.71 & 15.55 \\
\hline \multirow{2}{*}{$\mathrm{NW}+\mathrm{ADW}+\mathrm{TWW}$} & $0-30$ & 13.80 & 15.84 & 6.85 & 4.49 & 15.55 \\
\hline & $30-60$ & 14.23 & 16.16 & 7.28 & 4.71 & 17.00 \\
\hline \multirow{2}{*}{ USW } & $0-30$ & 13.80 & 15.94 & 6.74 & 4.80 & 16.19 \\
\hline & $30-60$ & 13.70 & 16.05 & 6.85 & 4.71 & 15.55 \\
\hline
\end{tabular}

Irrigation water qualities*: Nile Water (NW), Agriculture Drainage Water (ADW), Treated Waste Water (TWW), Untreated Sewage Water (USW). ${ }^{* *}$ Exchangeable sodium percentage $E S P=\frac{N a}{C E C} * 100$ 
Table 7. Long term effect of different irrigation water qualities on the soluble cations and anions (in 1:2.5 soil water extract) on the studied soil samples at different depths.

\begin{tabular}{|c|c|c|c|c|c|c|c|c|c|c|}
\hline \multirow{2}{*}{$\begin{array}{c}\text { Irrigation } \\
\text { water qualities } \\
*\end{array}$} & \multirow[t]{2}{*}{$\begin{array}{l}\text { Depth } \\
\text { Cm }\end{array}$} & \multirow[t]{2}{*}{$\begin{array}{c}\text { EC } \\
\text { dsm }^{-1}\end{array}$} & \multicolumn{4}{|c|}{$\begin{array}{l}\text { Soluble cations } \\
\text { mmol }_{\mathrm{c}} \mathbf{l}^{-1}\end{array}$} & \multicolumn{4}{|c|}{$\begin{array}{c}\text { Soluble anions } \\
\text { mmolc }^{1^{-1}}\end{array}$} \\
\hline & & & $\mathrm{Ca}^{++}$ & $\mathrm{Mg}^{++}$ & $\mathrm{Na}^{+}$ & $\mathbf{K}^{+}$ & $\mathrm{CO}_{3}=$ & $\mathrm{HCO}_{3}{ }^{-}$ & $\mathrm{Cl}^{-}$ & $\mathrm{SO}_{4}=$ \\
\hline \multirow{2}{*}{ NW } & $0-30$ & 2.19 & 7.11 & 6.12 & 9.49 & 0.17 & 0.00 & 5.42 & 7.09 & 10.38 \\
\hline & $30-60$ & 2.10 & 7.08 & 6.11 & 8.68 & 0.17 & 0.00 & 5.26 & 7.00 & 9.78 \\
\hline \multirow{2}{*}{ ADW } & $0-30$ & 3.68 & 10.61 & 9.25 & 15.76 & 0.43 & 0.00 & 7.34 & 9.36 & 19.35 \\
\hline & $30-60$ & 3.59 & 10.43 & 8.97 & 16.06 & 0.44 & 0.00 & 7.25 & 9.14 & 19.51 \\
\hline \multirow{2}{*}{ NW + ADW } & $0-30$ & 2.98 & 9.03 & 6.76 & 13.71 & 0.30 & 0.00 & 6.96 & 8.80 & 14.04 \\
\hline & $30-60$ & 2.93 & 9.02 & 7.58 & 12.42 & 0.28 & 0.00 & 6.83 & 8.63 & 13.84 \\
\hline \multirow{2}{*}{$\begin{array}{c}\mathrm{NW}+\mathrm{ADW} \\
+\mathrm{TWW}\end{array}$} & $0-30$ & 2.78 & 9.46 & 6.90 & 11.14 & 0.30 & 0.00 & 6.46 & 8.59 & 12.75 \\
\hline & $30-60$ & 2.77 & 9.45 & 6.92 & 11.12 & 0.21 & 0.00 & 6.60 & 8.49 & 12.61 \\
\hline \multirow{2}{*}{ USW } & $0-30$ & 2.95 & 9.02 & 7.71 & 12.77 & 0.33 & 0.00 & 6.96 & 9.30 & 13.57 \\
\hline & $30-60$ & 2.90 & 8.8 & 7.51 & 12.36 & 0.30 & 0.00 & 6.83 & 8.63 & 13.51 \\
\hline
\end{tabular}

Irrigation water qualities*: Nile Water (NW), Agriculture Drainage Water (ADW), Treated Waste Water (TWW) and Untreated Sewage Water (USW).

Table 8. Long term effect of different irrigation water qualities on the available of NPK (mg $\left.\mathrm{kg}^{-1}\right)$ and equivalent fertilizer units $\left(\mathrm{kg} \mathrm{fed}^{-1}\right)$ on the studied soils at different soil depths.

\begin{tabular}{|c|c|c|c|c|c|c|c|}
\hline \multirow{2}{*}{$\begin{array}{l}\text { Irrigation water } \\
\text { qualities * }\end{array}$} & \multirow{2}{*}{$\begin{array}{l}\text { Depth } \\
\text { Cm }\end{array}$} & \multicolumn{3}{|c|}{ NPK (mg kg-1) } & \multicolumn{3}{|c|}{ fertilizer units ( $\left.\mathrm{kg} \mathrm{fed}^{-1}\right)$} \\
\hline & & $\mathbf{N}$ & $\mathbf{P}$ & $\mathbf{K}$ & $\mathbf{N}$ & $\mathbf{P}_{2} \mathrm{O}_{5}$ & $\mathrm{~K}_{2} \mathrm{O}$ \\
\hline \multirow[t]{2}{*}{ NW } & $0-30$ & 54.37 & 4.86 & 198.00 & 54.37 & 11.13 & 237.60 \\
\hline & $30-60$ & 50.12 & 3.62 & 171.00 & 50.12 & 8.29 & 205.20 \\
\hline \multirow[t]{2}{*}{ ADW } & $0-30$ & 72.50 & 7.11 & 298.00 & 72.50 & 16.28 & 357.60 \\
\hline & $30-60$ & 68.10 & 6.39 & 245.00 & 68.10 & 14.63 & 294.00 \\
\hline \multirow[t]{2}{*}{$\mathrm{NW}+\mathrm{ADW}$} & $0-30$ & 61.82 & 6.12 & 219.00 & 61.82 & 14.01 & 262.80 \\
\hline & $30-60$ & 60.17 & 5.31 & 203.00 & 60.17 & 12.16 & 243.60 \\
\hline \multirow{2}{*}{$\begin{array}{l}\text { NW + ADW } \\
+ \text { TWW }\end{array}$} & $0-30$ & 79.32 & 7.76 & 327.00 & 79.32 & 17.77 & 392.40 \\
\hline & $30-60$ & 71.51 & 6.81 & 305.00 & 71.51 & 15.59 & 366.00 \\
\hline \multirow[t]{2}{*}{ USW } & $0-30$ & 89.49 & 8.10 & 389.00 & 89.49 & 18.55 & 466.80 \\
\hline & $30-60$ & 80.21 & 7.40 & 325.00 & 80.21 & 16.95 & 390.00 \\
\hline
\end{tabular}

Irrigation water qualities*: Nile Water (NW), Agriculture Drainage Water (ADW), Treated Waste Water (TWW) and Untreated Sewage Water (USW). $\quad \mathrm{P}_{2} \mathrm{O}_{5}=\mathrm{P} X 2.29 \quad \mathrm{~K}_{2} \mathrm{O}=\mathrm{K} \times 1.20$ 
Table 9. Long term effect of different irrigation water qualities on the available of micronutrient and heavy metals $\left(\mathrm{mg} \mathrm{kg}^{-1}\right)$ on the studied soils at different soil depths:

\begin{tabular}{cccccccc}
\hline $\begin{array}{c}\text { Irrigation water } \\
\text { qualities* }\end{array}$ & Depth $\mathbf{~ m ~}$ & Fe & Zn & Mn & $\mathbf{C u}$ & $\mathbf{C d}$ & $\mathbf{P b}$ \\
\hline NW & $0-30$ & 36.72 & 0.48 & 3.06 & 1.85 & 0.25 & 3.10 \\
& $30-60$ & 30.04 & 0.38 & 2.79 & 1.25 & 0.21 & 2.30 \\
ADW & $0-30$ & 71.06 & 2.09 & 5.49 & 2.56 & 0.32 & 7.30 \\
& $30-60$ & 68.49 & 1.34 & 3.68 & 1.89 & 0.28 & 5.90 \\
NW + ADW & $0-30$ & 68.40 & 1.90 & 4.94 & 2.12 & 0.30 & 5.39 \\
NW + ADW & $30-60$ & 60.66 & 1.22 & 3.51 & 1.80 & 0.28 & 4.10 \\
+TWW & $0-30$ & 81.62 & 2.80 & 6.89 & 5.15 & 0.43 & 7.89 \\
USW & $30-60$ & 80.96 & 2.40 & 6.63 & 4.44 & 0.36 & 6.65 \\
& $0-30$ & 86.05 & 3.00 & 8.00 & 6.34 & 0.53 & 10.5 \\
& $30-60$ & 81.79 & 2.83 & 6.93 & 5.52 & 0.45 & 8.40 \\
\hline
\end{tabular}

Irrigation water qualities*: Nile Water (NW), Agriculture Drainage Water (ADW), Treated Waste Water (TWW) and Untreated Sewage Water (USW)

Table 10. The concentration of NPK $\left(\mathrm{mgl}^{-1}\right)$ in different irrigation water qualities and its equivalent from fertilizers unites ( $\mathrm{kg} /$ feddan/season), during the summer season for maize crop.

\begin{tabular}{|c|c|c|c|c|c|c|c|c|c|}
\hline \multirow{2}{*}{$\begin{array}{l}\text { Irrigation } \\
\text { water } \\
\text { qualities* }\end{array}$} & \multirow{2}{*}{$\begin{array}{l}\text { Nutrient } \\
\text { element } \\
\text { mgl-1 }^{-1}\end{array}$} & \multicolumn{6}{|c|}{ Month } & \multicolumn{2}{|c|}{$\begin{array}{c}\text { Average amount } \\
\text { nutrients } \\
\text { (kg/feddan/season) }\end{array}$} \\
\hline & & May & June & July & Aug. & Sep. & Average & Values & $\begin{array}{l}\text { Fertilizer } \\
\text { units }\end{array}$ \\
\hline \multirow{4}{*}{ NW } & $\mathrm{N}$ & 5.82 & 6.00 & 6.12 & 6.24 & 5.88 & 6.01 & 12.63 & 12.63 \\
\hline & $P$ & 3.00 & 3.15 & 3.06 & 2.88 & 2.91 & 3.00 & 6.30 & 14.43 \\
\hline & K & 0.65 & 0.70 & 0.68 & 0.61 & 0.62 & 0.65 & 1.37 & 1.64 \\
\hline & $\mathrm{N}$ & 14.55 & 15.00 & 15.30 & 15.60 & 14.70 & 15.03 & 31.56 & 31.56 \\
\hline \multirow[t]{3}{*}{ ADW } & $\mathrm{P}$ & 4.40 & 4.62 & 4.49 & 4.22 & 4.27 & 4.40 & 9.24 & 21.16 \\
\hline & $\mathrm{K}$ & 1.85 & 2.00 & 1.92 & 1.74 & 1.78 & 1.86 & 3.90 & 4.68 \\
\hline & $\mathrm{N}$ & 15.91 & 16.40 & 16.73 & 17.06 & 16.07 & 16.43 & 34.51 & 34.51 \\
\hline \multirow[t]{3}{*}{ NW+ ADW } & $\mathrm{P}$ & 5.14 & 5.40 & 5.24 & 4.93 & 4.99 & 5.14 & 10.79 & 24.72 \\
\hline & K & 1.72 & 1.86 & 1.79 & 1.62 & 1.65 & 1.73 & 3.63 & 4.35 \\
\hline & $\mathrm{N}$ & 21.95 & 22.63 & 23.08 & 23.54 & 22.18 & 22.68 & 47.62 & 47.62 \\
\hline \multirow{3}{*}{$\begin{array}{c}\mathrm{NW}+ \\
\text { ADW+TWW }\end{array}$} & $\mathrm{P}$ & 7.29 & 7.65 & 7.44 & 7.00 & 7.07 & 7.35 & 15.44 & 35.35 \\
\hline & K & 2.30 & 2.48 & 2.39 & 2.16 & 2.21 & 2.31 & 4.85 & 5.82 \\
\hline & $\mathrm{N}$ & 18.77 & 19.35 & 19.74 & 20.12 & 18.96 & 19.39 & 40.71 & 40.71 \\
\hline \multirow[t]{2}{*}{ USW } & $\mathrm{P}$ & 6.70 & 7.04 & 6.83 & 6.43 & 6.50 & 6.70 & 14.07 & 32.22 \\
\hline & $\mathrm{K}$ & 1.65 & 1.78 & 1.72 & 1.55 & 1.58 & 1.66 & 3.48 & 4.17 \\
\hline
\end{tabular}

Irrigation water qualities*: Nile Water (NW), Agriculture Drainage Water (ADW), Treated Waste Water (TWW) and Untreated Sewage Water (USW).The calculation under studied areas were taken into consideration the water requirement of maize crop (Zea mays cv. hybrid 704) as a summer crop was $2100 \mathrm{~m}^{3} / \mathrm{feddan} / \mathrm{season}$. $\mathrm{P}_{2} \mathrm{O}_{5}=\mathrm{P} \times 2.29$ $\mathrm{K}_{2} \mathrm{O}=\mathrm{K} \times 1.20$ 
Table 11. The concentration of NPK ( $\left.\mathrm{mgl}^{-1}\right)$ and its equivalent from fertilizers unites ( $\left.\mathrm{kg} / \mathrm{feddan} / \mathrm{season}\right)$, in irrigation water qualities during the winter season for wheat crop.

\begin{tabular}{|c|c|c|c|c|c|c|c|c|c|}
\hline \multirow{2}{*}{$\begin{array}{l}\text { Irrigation water } \\
\text { qualities* }\end{array}$} & \multirow[t]{2}{*}{$\begin{array}{l}\text { Nutrient } \\
\text { element } \\
\left(\mathrm{mgl}^{-1}\right)\end{array}$} & \multicolumn{6}{|c|}{ Month } & \multicolumn{2}{|c|}{$\begin{array}{c}\text { Average amount } \\
\text { nutrients } \\
\text { (kg/feddan/season) }\end{array}$} \\
\hline & & Nov. & Dec. & Jan. & Feb. & Mar. & Average & Values & $\begin{array}{c}\text { Fertilizer } \\
\text { units }\end{array}$ \\
\hline \multirow{3}{*}{ NW } & $\mathrm{N}$ & 5.88 & 5.99 & 6.13 & 5.99 & 5.91 & 5.98 & 7.18 & 7.18 \\
\hline & $\mathrm{P}$ & 3.06 & 2.97 & 3.06 & 2.96 & 3.00 & 3.01 & 3.61 & 8.27 \\
\hline & $\mathrm{K}$ & 0.67 & 0.66 & 0.64 & 0.67 & 0.62 & 0.65 & 0.78 & 0.94 \\
\hline \multirow{3}{*}{ ADW } & $\mathrm{N}$ & 14.7 & 14.98 & 15.33 & 14.99 & 15.02 & 15.00 & 18.00 & 18.00 \\
\hline & $\mathrm{P}$ & 4.49 & 4.35 & 4.48 & 4.34 & 4.39 & 4.41 & 5.29 & 12.12 \\
\hline & K & 1.91 & 1.87 & 1.81 & 1.9 & 1.76 & 1.85 & 2.22 & 2.66 \\
\hline \multirow{3}{*}{ NW+ ADW } & $\mathrm{N}$ & 16.31 & 16.37 & 16.76 & 16.39 & 15.91 & 16.35 & 19.62 & 19.62 \\
\hline & $\mathrm{P}$ & 5.24 & 5.09 & 5.24 & 5.07 & 5.13 & 5.15 & 6.18 & 14.16 \\
\hline & $\mathrm{K}$ & 1.77 & 1.74 & 1.68 & 1.76 & 1.63 & 1.72 & 2.06 & 2.47 \\
\hline \multirow{4}{*}{$\begin{array}{c}\text { NW+ ADW } \\
+ \text { TWW }\end{array}$} & $\mathrm{N}$ & 22.54 & 22.59 & 23.32 & 22.61 & 21.97 & 22.61 & 27.13 & 27.13 \\
\hline & $\mathrm{P}$ & 7.44 & 7.21 & 7.42 & 7.2 & 7.28 & 7.31 & 8.77 & 20.09 \\
\hline & K & 2.37 & 2.32 & 2.25 & 2.36 & 2.18 & 2.30 & 2.76 & 3.31 \\
\hline & $\mathrm{N}$ & 18.98 & 19.32 & 19.78 & 19.33 & 19.25 & 19.33 & 23.20 & 23.20 \\
\hline \multirow[t]{2}{*}{ USW } & $\mathrm{P}$ & 6.83 & 6.63 & 6.82 & 6.61 & 6.69 & 6.72 & 8.06 & 18.46 \\
\hline & $\mathrm{K}$ & 1.7 & 1.66 & 1.62 & 1.69 & 1.57 & 1.65 & 1.98 & 2.37 \\
\hline
\end{tabular}

Irrigation water qualities*: Nile Water (NW), Agriculture Drainage Water (ADW), Treated Waste Water (TWW) and Untreated Sewage Water (USW). The calculation under studied areas were taken into consideration the water requirement of wheat crop (Triticum aestivum cv. Shakha 93) as a winter crop was $1200 \mathrm{~m}^{3} \backslash$ feddan $\backslash$ season., $\mathrm{P}_{2} \mathrm{O}_{5}=\mathrm{P}$ $\mathrm{X} 2.29, \mathrm{~K}_{2} \mathrm{O}=\mathrm{K} X 1.20$ 
Table 12. Calculation of fertilizers units ( $\mathrm{kg} \backslash$ feddan $\backslash$ season) which will be added for maize as a summer crop after deducting the amount of fertilizers unites introduced with irrigation water and available from soil.

\begin{tabular}{|c|c|c|c|c|c|c|c|c|c|c|c|c|c|c|c|}
\hline \multirow[t]{2}{*}{$\begin{array}{l}\text { Irrigation } \\
\text { water } \\
\text { qualities* }^{*}\end{array}$} & \multicolumn{3}{|c|}{\begin{tabular}{c} 
Contribution of \\
irrigation water \\
from fertilizer \\
unites \\
(kglfeddan\} $\\
{\text { season) }} \\
{\text { which will be }} \\
{\text { introduced during }} \\
{\text { summer season for }} \\
{\text { maize crop }}$ & \multicolumn{3}{|c|}{$\begin{array}{c}\text { Contribution of soil } \\
\text { from fertilizer } \\
\text { unites } \\
\text { (kg\feddan } \backslash \text { season) } \\
\text { which will available } \\
\text { during summer } \\
\text { season for maize } \\
\text { crop }\end{array}$} & \multicolumn{3}{|c|}{$\begin{array}{c}\text { Total contribution of } \\
\text { irrigation water and } \\
\text { soil from fertilizer } \\
\text { unites } \\
\text { (kglfeddan } \backslash \text { season) } \\
\text { which will available } \\
\text { during summer } \\
\text { season for maize } \\
\text { crop }\end{array}$} & \multicolumn{3}{|c|}{$\begin{array}{l}\text { Recommend } \\
\text { ed doses } \\
\text { (kg\feddan } \backslash \\
\text { season) for } \\
\text { maize crop }\end{array}$} & \multicolumn{3}{|c|}{$\begin{array}{c}\text { Fertilizer units } \\
\text { (kg\feddan } \backslash \text { season) } \\
\text { that must be added to } \\
\text { complete the fertlizer } \\
\text { requirement }\end{array}$} \\
\hline & $\mathbf{N}$ & $\mathbf{P}_{2} \mathrm{O}_{5}$ & $\begin{array}{l}\mathrm{K}_{2} \\
\mathrm{O}\end{array}$ & $\mathbf{N}$ & $\mathrm{P}_{2} \mathrm{O}_{5}$ & $\mathrm{~K}_{2} \mathrm{O}$ & $\mathbf{N}$ & $\mathrm{P}_{2} \mathrm{O}_{5}$ & $\mathrm{~K}_{2} \mathrm{O}$ & $\mathbf{N}$ & $\begin{array}{c}\mathbf{P}_{2} \\
\mathbf{O} \\
5\end{array}$ & $\begin{array}{l}\mathrm{K} \\
2 \\
\mathrm{O}\end{array}$ & $\mathbf{N}$ & $\mathrm{P}_{2} \mathrm{O}_{5}$ & $\mathrm{~K}_{2} \mathrm{O}$ \\
\hline NW & 12.63 & 14.43 & 1.64 & 54.37 & 11.13 & $\begin{array}{c}237.6 \\
0\end{array}$ & $\begin{array}{c}67.0 \\
0\end{array}$ & 25.56 & 239.24 & 120 & 30 & 24 & 53.00 & 4.44 & -215.24 \\
\hline ADW & 31.56 & 21.16 & 4.68 & 72.50 & 16.28 & $\begin{array}{c}357.6 \\
0\end{array}$ & $\begin{array}{c}104 . \\
06\end{array}$ & 37.44 & 362.28 & 120 & 30 & 24 & 15.94 & -7.44 & -338.28 \\
\hline NW+ADW & 34.51 & 24.72 & 4.35 & 61.82 & 14.01 & $\begin{array}{c}262.8 \\
0 \\
\end{array}$ & $\begin{array}{c}96.3 \\
3 \\
\end{array}$ & 38.73 & 267.15 & 120 & 30 & 24 & 23.67 & -8.73 & -243.15 \\
\hline $\begin{array}{l}\text { NW + ADW } \\
\text { +TWW }\end{array}$ & 47.62 & 35.35 & 5.82 & 79.32 & 17.77 & $\begin{array}{c}392.4 \\
0\end{array}$ & $\begin{array}{c}126 . \\
94\end{array}$ & 52.83 & 398.22 & 120 & 30 & 24 & -6.94 & $\begin{array}{c}- \\
23.12\end{array}$ & -374.22 \\
\hline USW & 40.71 & 32.22 & 4.17 & 89.49 & 18.55 & $\begin{array}{c}466.8 \\
0\end{array}$ & $\begin{array}{c}130 . \\
20\end{array}$ & 50.77 & 470.97 & 120 & 30 & 24 & $\begin{array}{c}- \\
10.20\end{array}$ & $\begin{array}{c}- \\
20.77\end{array}$ & -446.97 \\
\hline
\end{tabular}}
\end{tabular}

Irrigation water qualities*: Nile Water (NW), Agriculture Drainage Water (ADW), Treated Waste Water (TWW) and Untreated Sewage Water (USW). (-) Negative sign means that the amount of fertilizer units is high due to the addition of available amount from irrigation water and/or soil. (+) Positive sign means that the amount of fertilizer units which will be added to complete the fertilizers requirement. 
Table 13. Calculation of fertilizers units (kg $\backslash$ feddan $\backslash$ season) which will be added for wheat as a winter crop after deducting the amount of fertilizers unites introduced with irrigation water and available from soil

\begin{tabular}{|c|c|c|c|c|c|c|c|c|c|c|c|c|c|c|c|}
\hline \multirow[t]{2}{*}{$\begin{array}{l}\text { Irrigation } \\
\text { water } \\
\text { qualities * }\end{array}$} & \multicolumn{3}{|c|}{$\begin{array}{c}\text { Contribution of } \\
\text { irrigation water } \\
\text { from fertilizer } \\
\text { unites } \\
\text { (kg/feddan/season) } \\
\text { which will be } \\
\text { introduced during } \\
\text { winter season for } \\
\text { wheat crop }\end{array}$} & \multicolumn{3}{|c|}{$\begin{array}{c}\text { Contribution of } \\
\text { soil from } \\
\text { fertilizer unites } \\
\text { (kg/feddan/seaso } \\
\text { n) } \\
\text { which will } \\
\text { available during } \\
\text { winter season for } \\
\text { wheat crop }\end{array}$} & \multicolumn{3}{|c|}{$\begin{array}{c}\text { Total } \\
\text { contribution of } \\
\text { irrigation water } \\
\text { and soil from } \\
\text { fertilizer unites } \\
\text { (kg/feddan/seaso } \\
\text { n) } \\
\text { which will } \\
\text { available during } \\
\text { winter season for } \\
\text { wheat crop }\end{array}$} & \multicolumn{3}{|c|}{$\begin{array}{c}\text { Recommen } \\
\text { ded doses } \\
\text { (kg/feddan } \\
\text { / season) } \\
\text { for wheat } \\
\text { crop }\end{array}$} & \multicolumn{3}{|c|}{$\begin{array}{c}\text { Fertilizer units } \\
\text { (kg/feddan/ season) } \\
\text { that must be added to } \\
\text { complete the fertlizer } \\
\text { requirement }\end{array}$} \\
\hline & $\mathbf{N}$ & $\mathbf{P}_{2} \mathrm{O}_{5}$ & $\begin{array}{l}\mathrm{K}_{2} \\
\mathrm{O}\end{array}$ & $\mathbf{N}$ & $\begin{array}{l}\mathrm{P}_{2} \\
\mathrm{O}_{5}\end{array}$ & $\begin{array}{l}\mathrm{K}_{2} \\
\mathbf{O}\end{array}$ & $\mathbf{N}$ & $\begin{array}{c}\mathrm{P}_{2} \mathrm{O} \\
5\end{array}$ & $\mathbf{K}_{2} \mathbf{O}$ & $\mathbf{N}$ & $\begin{array}{c}\mathbf{P}_{2} \\
\mathrm{O} \\
5\end{array}$ & $\begin{array}{c}\mathrm{K} \\
2 \\
\mathrm{O}\end{array}$ & $\mathbf{N}$ & $\mathbf{P}_{2} \mathbf{O}_{5}$ & $\mathrm{~K}_{2} \mathrm{O}$ \\
\hline NW & 7.18 & 8.27 & 0.94 & 54.37 & $\begin{array}{l}1 \\
1\end{array}$ & $\begin{array}{c}237 . \\
6\end{array}$ & $\begin{array}{c}61.5 \\
5\end{array}$ & $\begin{array}{c}19.4 \\
0\end{array}$ & $\begin{array}{c}238.5 \\
4\end{array}$ & 75 & 15 & 24 & 13.45 & -4.40 & -214.54 \\
\hline ADW & 18.00 & 12.12 & 2.66 & 72.50 & 16 & $\begin{array}{c}357 . \\
6 \\
\end{array}$ & $\begin{array}{c}90.5 \\
0\end{array}$ & $\begin{array}{c}28.4 \\
0\end{array}$ & $\begin{array}{c}360.2 \\
6\end{array}$ & 75 & 15 & 24 & $\begin{array}{c}- \\
15.50\end{array}$ & -13.40 & -336.26 \\
\hline $\begin{array}{c}\text { NW+AD } \\
\text { W }\end{array}$ & 19.26 & 14.16 & 2.47 & 61.82 & $\begin{array}{l}14 \\
01 \\
\end{array}$ & $\begin{array}{c}262 . \\
8\end{array}$ & $\begin{array}{c}81.0 \\
8 \\
\end{array}$ & $\begin{array}{c}28.1 \\
7 \\
\end{array}$ & $\begin{array}{c}265.2 \\
7 \\
\end{array}$ & 75 & 15 & 24 & -6.08 & -13.17 & -241.27 \\
\hline $\begin{array}{c}\text { NW + } \\
\text { ADW } \\
+\mathrm{TWW}\end{array}$ & 27.13 & 20.09 & 3.31 & 79.32 & 77 & $\begin{array}{c}392 . \\
4\end{array}$ & $\begin{array}{c}106 \\
45\end{array}$ & $\begin{array}{c}37.8 \\
6\end{array}$ & $\begin{array}{c}395.7 \\
1\end{array}$ & 75 & 15 & 24 & $\begin{array}{c}- \\
31.45\end{array}$ & -22.86 & -371.71 \\
\hline USW & 23.20 & 18.46 & 2.37 & 89.49 & 55 & $\begin{array}{c}466 . \\
8\end{array}$ & $\begin{array}{r}112 . \\
69\end{array}$ & $\begin{array}{c}37.0 \\
1\end{array}$ & $\begin{array}{c}469.1 \\
7\end{array}$ & 75 & 15 & 24 & $\begin{array}{c}- \\
37.69\end{array}$ & -22.01 & -445.17 \\
\hline
\end{tabular}

Irrigation water qualities*: Nile Water (NW), Agriculture Drainage Water (ADW), Treated Waste Water (TWW) and Untreated Sewage Water (USW) (-) Negative sign means that the amount of fertilizer units is high due to the addition of available amount from irrigation water and/or soil. (+) Positive sign means that the amount of fertilizer units which will be added to complete the fertilizers requirement. 


\section{الثاثير طويل المدى لنوعيات مياه الري غير التقليدية على بعض خواص التربة وبرنامج التسميد}

\section{مجدي شاهين محمد"، أحمد جمعه عبده منسي، سيد عبد الرحن عابدين، محم كمال الدين عبد الدايم \\ 1 قسم الأراضي والمياه، كلية الزراعة، جامعة الأزهر، بالقاهرة، مصر}

mshahin58@azhae.edu.eg البريد الإليكتروني للباحث الرئيسي: *

\section{الملخص العربي}

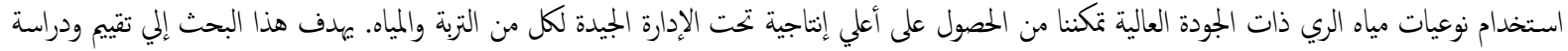

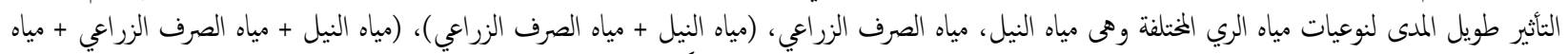

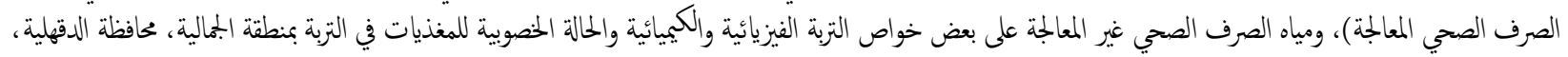

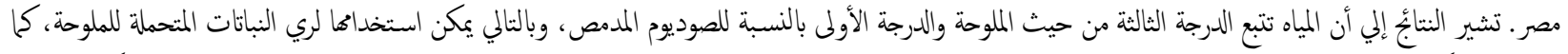

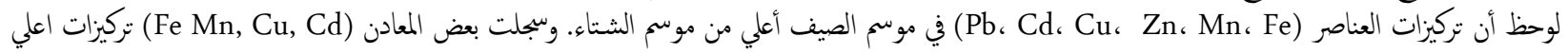

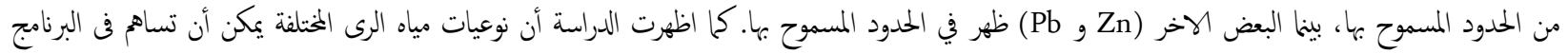

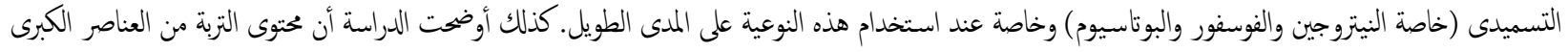

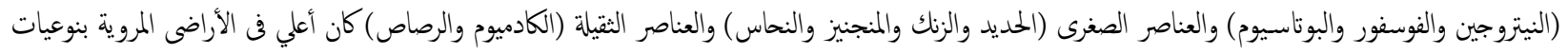

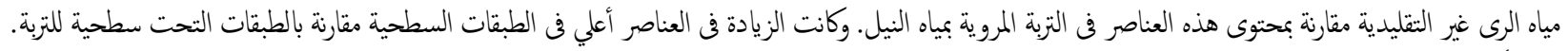

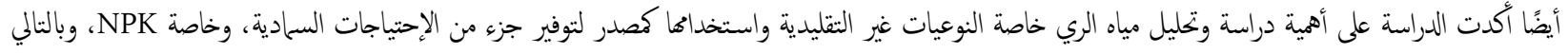

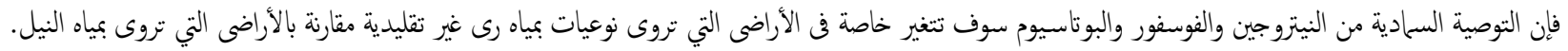

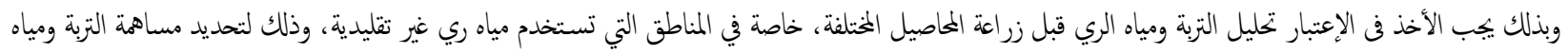

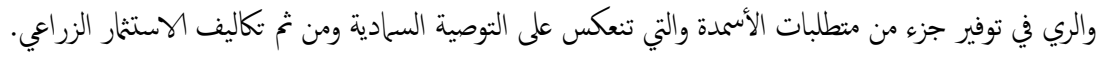
الكلمات المفتاحية: جودة مياه الري، خصائص التربة، برنامج التسميد. 